\title{
Geology
}

\section{Geologic, geochemical, and geophysical consequences of plume involvement in the Emeishan flood-basalt province}

\author{
Yi-Gang Xu, Bin He, Sun-Lin Chung, Martin A. Menzies and Frederick A. Frey
}

Geology 2004;32;917-920

doi: $10.1130 / G 20602.1$

Email alerting services

Subscribe

Permission request click www.gsapubs.org/cgi/alerts to receive free e-mail alerts when new articles cite this article

click www.gsapubs.org/subscriptions/ to subscribe to Geology

click http://www.geosociety.org/pubs/copyrt.htm\#gsa to contact GSA

Copyright not claimed on content prepared wholly by U.S. government employees within scope of their employment. Individual scientists are hereby granted permission, without fees or further requests to GSA, to use a single figure, a single table, and/or a brief paragraph of text in subsequent works and to make unlimited copies of items in GSA's journals for noncommercial use in classrooms to further education and science. This file may not be posted to any Web site, but authors may post the abstracts only of their articles on their own or their organization's Web site providing the posting includes a reference to the article's full citation. GSA provides this and other forums for the presentation of diverse opinions and positions by scientists worldwide, regardless of their race, citizenship, gender, religion, or political viewpoint. Opinions presented in this publication do not reflect official positions of the Society.

\section{Notes}




\title{
Downloaded from geology.gsapubs.org on 19 September 2009
Geologic, geochemical, and geophysical consequences of plume involvement in the Emeishan flood-basalt province
}

\author{
Yi-Gang Xu* $\mathrm{He}$ - Guangzhou Institute of Geochemistry, Chinese Academy of Sciences, 510640 Guangzhou, China \\ Sun-Lin Chung Department of Geosciences, National Taiwan University, Taipei 10699, Taiwan \\ Martin A. Menzies Department of Geology, Royal Holloway University of London, Egham, Surrey TW20 OEX, UK \\ Frederick A. Frey Department of Earth, Atmospheric and Planetary Sciences, Massachusetts Institute of Technology, \\ Cambridge, Massachusetts 02139, USA
}

\begin{abstract}
Prevolcanic kilometer-scale lithospheric doming in the Emeishan large igneous province, southwest China, allows us to evaluate the spatial and temporal consequences of uplift on the paleogeography, geology, geochemistry, and geophysics of the region. Systematic spatial variations are observed across the domal structure in the distribution and thickness of clastic and carbonate sediments, the extent of erosion, thickness, and chemistry of volcanic rocks, and the crust-mantle structure. These features, which are best explained by a mantle plume, may be used to track older plume sites in the geologic record.
\end{abstract}

Keywords: paleogeography, geochemistry, geophysics, plumelithosphere interaction, Emeishan basalt.

\section{INTRODUCTION}

The plume hypothesis has been widely adopted to explain the formation of time-progressive ocean islands and large igneous provinces, such as oceanic plateaus and continental flood basalts (e.g., Morgan, 1971; White and McKenzie, 1989; Campbell and Griffiths, 1990; Coffin and Eldholm, 1994). This hypothesis is now challenged because some fundamental aspects predicted by the modeling of plumes are said to be lacking in classic regions like Iceland and Yellowstone (e.g., Foulger and Natland, 2003). Instead of invoking a "bottom-up" process, these researchers favor a "top-down" hypothesis (Anderson, 2001) for the formation of large igneous provinces, in which shallow lithospheric processes may fuel melt production. However, controversy prevails as to whether current resolution of seismic data is sufficient to detect small thermal anomalies such as mantle plumes (DePaolo and Manga, 2003; Foulger and Natland, 2003). It seems clear that there is not a plume at every hotspot and that there may be different types of hotspots rising from different levels of Earth's interior (Courtillot et al., 2003; Montelli et al., 2004).

Seismic investigations help trace mantle plumes in modern, active hotspots, but are of limited benefit in identifying ancient plumes, mainly because geophysics provides us with a snapshot of Earth's presentday structure. Consequently, the geologic "footprint" associated with thermal anomalies provides the clues to tracing ancient plumes. According to some theoretical models, prevolcanic lithospheric uplift is the most important criterion used to identify the presence of plumes (e.g., Campbell and Griffiths, 1990). Uplift is best recorded in the sedimentary record (Rainbird and Ernst, 2001) and in radial drainage patterns (Cox, 1989). The lack of such evidence, however, is an argument against the involvement of plumes in the formation of large igneous provinces (Czamanske et al., 1998; Sheth, 1999).

He et al. (2003) showed unambiguous evidence for a rapid crustal doming prior to the Emeishan flood volcanism (258-254 Ma) in southwestern China. Herein we use this domal structure as a new framework to examine several aspects of the Emeishan large igneous province,

*E-mail: yigangxu@gig.ac.cn. including (1) the middle Permian-Late Permian sedimentology, (2) the geochemistry of the volcanic successions, and (3) the seismic structure of the lithosphere to argue for a fossil mantle plume under this province.

\section{SEDIMENTOLOGY AND PALEOGEOGRAPHY}

To characterize the crustal processes prior to the Emeishan volcanism, we describe the nature of the strata underneath the basalts (i.e., the Maokou Formation; Fig. 1) and the basalt-sedimentary rock contact (He et al., 2003). Correlation and comparison of the biostratigraphy of the Maokou Formation reveal a systematic thinning of the strata beneath the Emeishan basalt; thinned carbonates are capped by a subaerial unconformity (Fig. 1), which in many cases is evident as karst paleotopography, zones of paleoweathering, and local and basal conglomerates. Provenance analysis of the clasts in the conglomerates indicates derivation from the uppermost Maokou Formation. Therefore, the stratigraphic thinning likely resulted from differential erosion due to regional uplift. Isopachs of the Maokou Formation further delineate an uplifted area with a roughly circular shape (Fig. 2), very similar to the crustal doming above an upwelling mantle plume predicted by theoretical modeling. Combining the extent of eroded Maokou limestone with erosion rates of $0.12-0.3 \mathrm{~mm} / \mathrm{yr}$ (He et al., 2003) allows us to estimate the amount of uplift necessary to produce these relationships. We estimate the duration of the kilometer-scale uplift to have been $<3 \mathrm{~m}$.y. and its radius to have been $>700 \mathrm{~km}$. The extent of uplift is $>1000 \mathrm{~m}$ in the core of the uplifted region (He et al., 2003). There is no known process on Earth, other than mantle plumes, that can form lithospheric domes $1000 \mathrm{~km}$ or more in radius and $>1 \mathrm{~km}$ high within several million years.

Lithospheric uplift prior to the Emeishan volcanism may have been responsible for (1) the rapid sea-level fall recorded by a regression at the boundary between the middle Permian and Upper Permian rocks in the western Yangtze craton and (2) the generation of clastic deposits surrounding the apex of the domal structure during the Late Permian (Fig. 1). This sea-level fall has been linked to the end-Guadalupian mass extinction, characterized by the disappearance of fusulinids, echinoderms, brachiopods, and bryozoans (Hallam and Wignall, 1999). The loss of the marine habitat due to sea-level fall has been proposed as the major mechanism for this biocrisis (Hallam and Wignall, 1999). A complement is to link the extinction to the eruption of the Emeishan basalts (Courtillot and Renne, 2003; Zhou et al., 2002). It is possible that both sea-level change related to plume-induced crustal uplift and the Emeishan volcanism contributed to the end-Guadalupian extinction.

No significant extension during formation of the Emeishan large igneous province is supported by the presence of a vast carbonate platform (i.e., stable sedimentary environment, Feng et al., 1997), the lack of a Late Permian dike swarm (Ernst and Buchan, 2003), and the fact that the Emeishan basalts uncomfortably overlie the Maokou Formation (Fig. 1). A significant sublithospheric thermal anomaly $(\sim 1600$ ${ }^{\circ} \mathrm{C}$, compared to $\sim 1300{ }^{\circ} \mathrm{C}$ of normal mantle) would be required to generate kilometer-scale lithospheric uplift in association with a melt

(C) 2004 Geological Society of America. For permission to copy, contact Copyright Permissions, GSA, or editing@geosociety.org. 


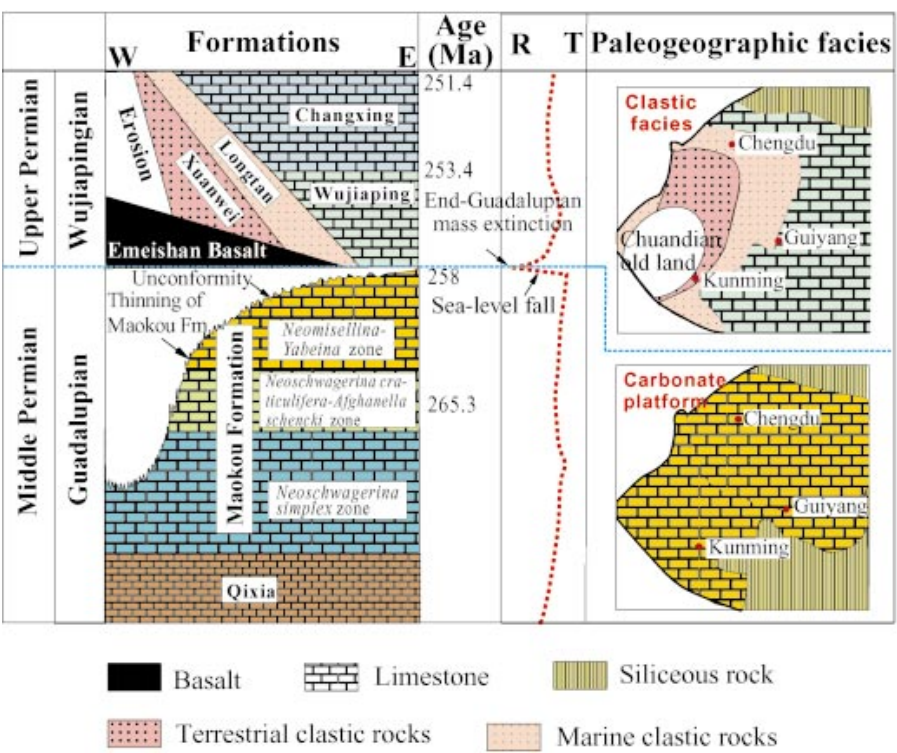

Figure 1. Changes in lithofacies, sea level, and paleogeographic pattern across boundary between middle Permian and Upper Permian rocks in Emeishan large igneous province. Three biostratigraphic units comprise Maokou limestone. Curve assigning thinning of Maokou Formation (from west to east) is after He et al. (2003). Rregression; T-transgression.

thickness of 15-25 km (see following), where lithospheric extension is minimal (e.g., McKenzie and Bickle, 1988). Late Permian paleogeography is defined by deposition on and off the circular uplift region (Fig. 1). For example, the distribution of Upper Permian terrestrial clastic deposits is largely confined to the domed area, and the shallowmarine limestones tended to be deposited in the areas beyond the uplifted area (Fig. 1). This observation and the circular sedimentary pattern strongly argue for a genetic link between plume-induced crustal uplift and the change in paleogeography across the middle PermianUpper Permian boundary.

The domal structure associated with the Emeishan large igneous province can be divided into inner, intermediate, and outer zones (Fig. 2) in terms of the extent of erosion of the Maokou Formation. The inner zone, where the erosion of the Maokou Formation is most apparent, is considered the impact site of the rising plume head ( $\mathrm{He}$ et al., 2003). The boundary of the inner zone is coincident with the Xiaojiang fault to the east, the Xichang-Qiaojia fault to the northeast, and the Jinhe fault to the northwest (Fig. 2). These faults are interpreted as syndoming structures because they controlled the very rapid deposition of clastic deposits in canyons and on alluvial fans. The extent of erosion is modest in the intermediate zone and is generally minor in the outer zone. Sedimentation in the areas beyond the Emeishan province, where the standard stratigraphic sequence of the Maokou Formation was established (Feng et al., 1997), was continuous throughout the Permian. Such a division of the domal structure is important because it provides a natural basis to subdivide the Emeishan large igneous province. Accordingly, the apex of the domed area may correspond to the plume head and the margins correspond to the plume peripheries.

\section{SPATIAL VARIATION IN THE BASALT GEOCHEMISTRY}

In this section we investigate compositional variations in the lavas from the center to the margin of the dome. For example, compositional variation would result from spatial zonation of mantle temperature that would lead to systematic variations in the degree of melting (Campbell and Griffiths, 1990). For this purpose, the volcanic stratigraphy at 10 locations in the inner and intermediate zones was sampled, and $>350$ samples were analyzed for major and trace element compositions $\mathrm{Xu}$

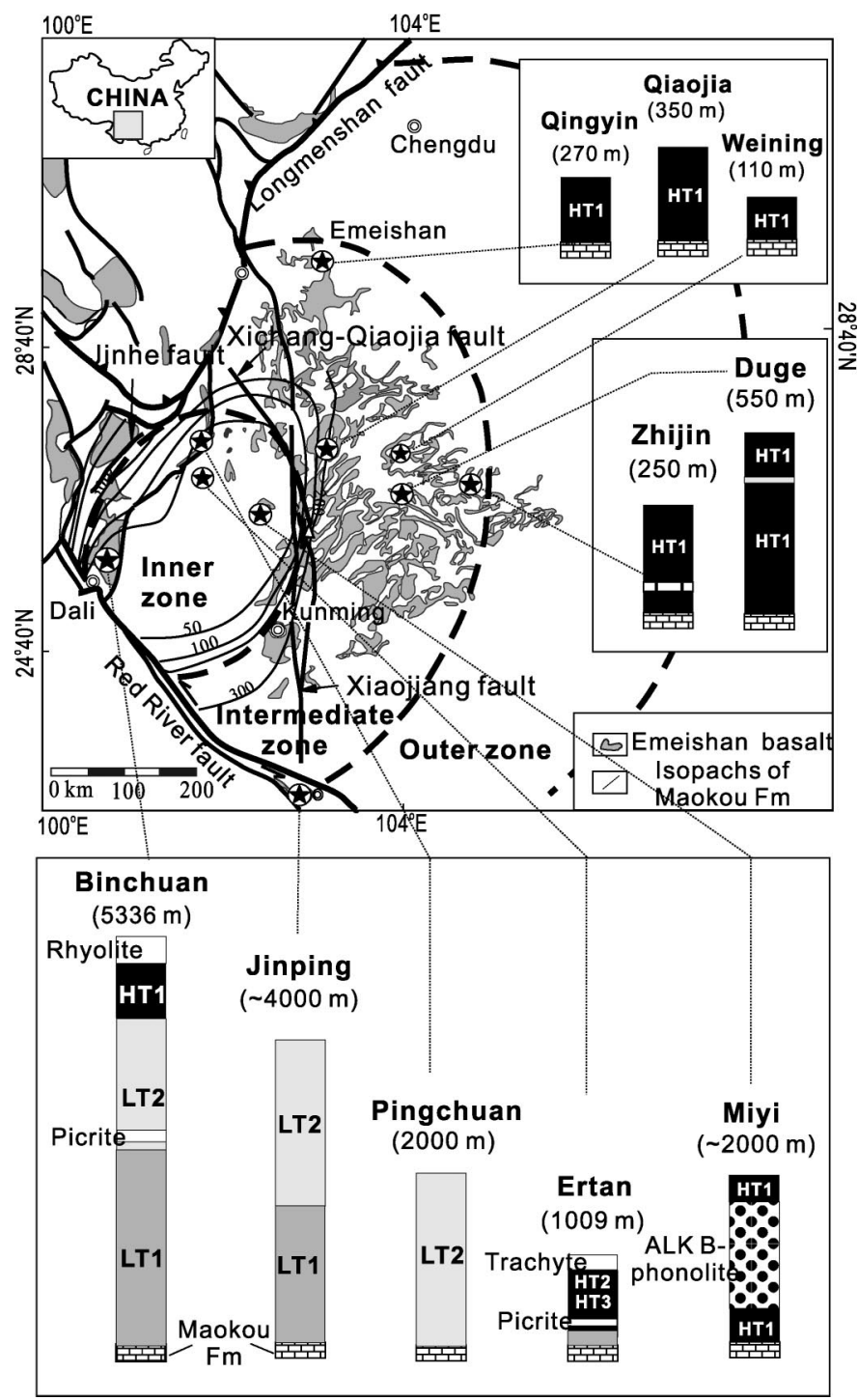

Figure 2. Distribution of Late Permian Emeishan basalts in southwestern China and stratigraphic variation of 10 representative lava successions. Also shown are isopachs of Maokou Formation that delineate subcircular domal structure formed prior to Emeishan volcanism (He et al., 2003). Dashed curves separate inner, intermediate, and outer zones of dome, which are characterized by varying extent of erosion of Maokou limestone. HT-high-Ti basalt; LT-low-Ti basalt; ALK - alkaline series. Classification of LT1, LT2, HT1, HT2, and HT3 and data are after Xiao et al. (2003) and Xu et al. $(2001,2003)$.

et al., 2001, 2003; Xiao et al., 2003). The Jinping section was initially within the inner zone and was displaced to the present position by Cenozoic sinistral movement along the Red River fault (Xiao et al., 2003). Data compilation reveals a systematic change in basalt type from the inner to intermediate zones (Fig. 2). In general, the domed region of the Emeishan large igneous province comprises thick (2000$5000 \mathrm{~m}$ ) sequences of dominant low-Ti volcanic rocks and subordinate picrites (Chung and Jahn, 1995), and high-Ti and alkaline lavas (Xu et al., 2001, 2003; Xiao et al., 2003). In contrast, thin sequences $(<500 \mathrm{~m})$ of high-Ti volcanic rocks mainly occur on the periphery of the domal structure (rock classification after $\mathrm{Xu}$ et al., 2001). Xu et al. (2001) showed that the high-Ti and low-Ti lavas require very different mantle conditions that are consistent with temperature variation across a plume head (Campbell and Griffiths, 1990). Application of rare earth element inversion techniques (McKenzie and O'Nions, 1991) reveals that the low-Ti lavas that originated at $60-140 \mathrm{~km}$ required $16 \%$ melt- 
ing and mantle temperatures $>1500{ }^{\circ} \mathrm{C}$. In contrast, the high-Ti lavas were generated at 75-100 km during events of much smaller degrees of melting $(1.5 \%)$ and at lower mantle temperatures $\left(<1500{ }^{\circ} \mathrm{C}\right)$. Therefore, the transition from the low-Ti to high-Ti lavas, which is associated with a change in thickness of the volcanic rocks (suggestive of different melt-production rates), was likely accompanied by a decreasing thermal gradient. The predominance of the thick low-Ti lavas in the inner zone (Fig. 2) suggests that the mantle beneath the core of the domal structure underwent a larger extent of partial melting than that under the marginal area. This suggestion and the occurrence of picrites in the inner zone are consistent with a hotter mantle beneath the dome center than beneath the dome periphery. A likely scenario is that a plume head was present underneath the inner zone.

There are additional observations that require complexity in this simple thermal-zonation model. Specifically, within the inner zone sections, high-Ti-HT1 and HT2-HT3-lavas occur in the uppermost parts of the Binchuan and Ertan sections, respectively, and a thick sequence of evolved alkaline lava (hawaiite to phonolite) occurs between high-Ti lavas in the Miyi section (Fig. 2). It is possible that these high-Ti and alkaline lavas are relatively young compared to lowTi lavas and reflect the waning of plume-related volcanism (Xu et al., 2001). However, to date we have no age constraints on lavas in these three sections. Nevertheless, low-Ti, HT2-HT3, and alkaline lavas occur exclusively in the inner zone, and they were subject to significant crustal contamination (Xu et al., 2001, 2003). These factors may be related to a larger degree of thermal remobilization of the lithosphere above the plume head compared to that above the plume periphery.

\section{SEISMIC DATA AND CRUST-MANTLE STRUCTURE}

Seismic data provide insights into the nature of the lithosphere, in particular the character of the transition between the crust and upper mantle. In relation to the domal structure outlined here, there is a gradual decrease in crustal thickness from the center to the margin of the dome (Fig. 3A). The crustal thickness in the inner zone ranges from 55 to $64 \mathrm{~km}$ (average $61.5 \mathrm{~km}$ ), which is considerably thicker than that beneath eastern China $(<35 \mathrm{~km})$, a typical nonrifted continental margin (Menzies et al., 2002). The crust in the intermediate zone is also relatively thick, ranging from 38 to $54 \mathrm{~km}$ (average $45 \mathrm{~km}$ ), but is thinner than in the inner zone. The data in the outer zone are sparse but define a range of 35-43 km (Fig. 3A). This seismic result is consistent with the petrogenetic model, indicating that melt production was higher in the inner zone.

Seismic tomographic modeling reveals that the lower crust in the inner zone has a high seismic P-wave velocity ranging from 7.1 to 7.8 km/s (Fig. 3B; Liu et al., 2001). The thickness of this high-velocity lower crust is as much as $25 \mathrm{~km}$ (average $20 \mathrm{~km}$ ), similar to that of high-velocity lower crust reported from volcanic rifted margins associated with large igneous provinces (Menzies et al., 2002). Although tomographic data are not available for other zones of the domed area, other investigations suggest that the crust outside of the inner zone is relatively thin $(<45 \mathrm{~km})$ and that the high-velocity layer is generally absent (Cui et al., 1987). Different crustal structures are therefore suggested for the inner and intermediate zones of the domed area. It is interesting to note that the outline of the high-velocity lower crust according to seismic data coincides with the domal structure defined on the basis of sedimentary rocks.

Furthermore, the tomographic results (Liu et al., 2001) reveal a lens-shaped, fast upper mantle (seismic velocity, $V p=8.1-8.6 \mathrm{~km} / \mathrm{s}$ ) below the high-velocity lower crust (Fig. 3B). The western and eastern margins of this seismically anomalous body correspond to longitudes of $100.8^{\circ} \mathrm{E}$ and $102.8^{\circ} \mathrm{E}$, respectively, which agree well with the geographic location of the inner zone (Fig. 3). It is the spatial proximity of the high $V \mathrm{p}$ body and the inner zone that leads us to suggest that

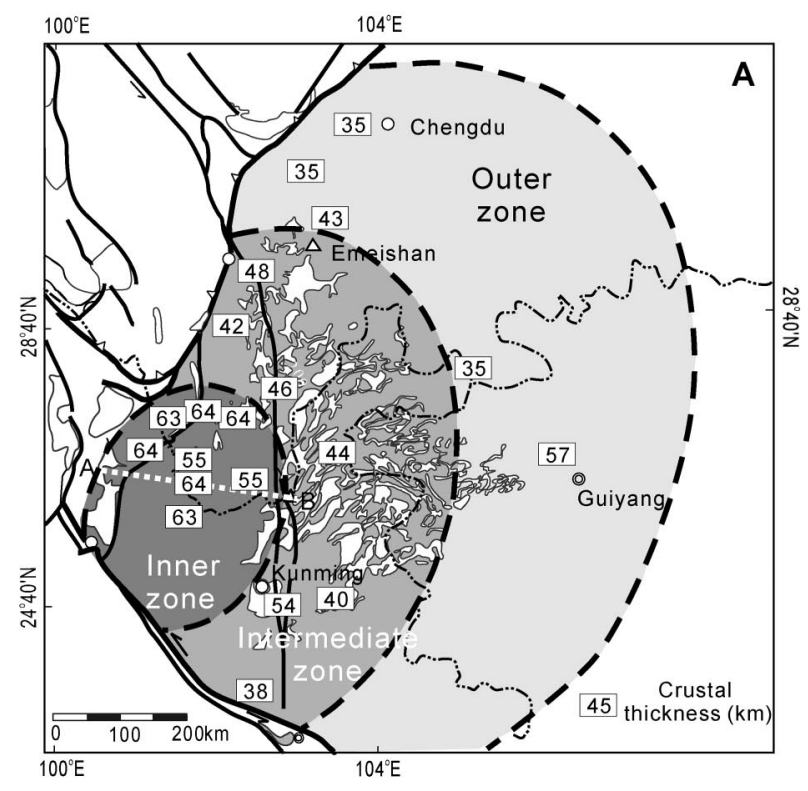

Lijiang

$\left(100.2^{\circ} \mathrm{E}, 26.9^{\circ} \mathrm{N}\right)$

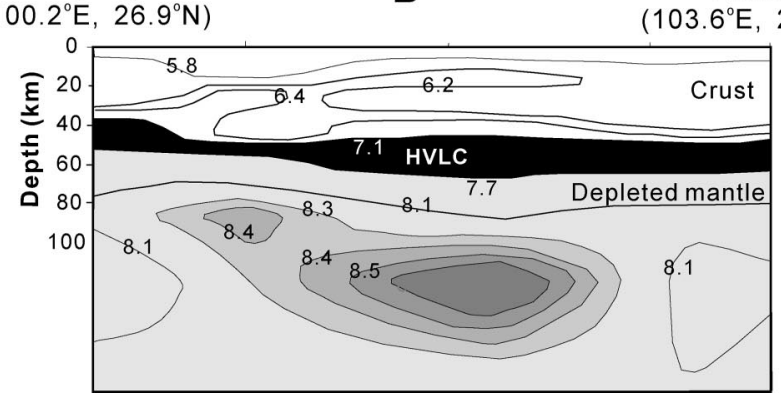

Figure 3. A: Crustal thickness data plotted over domal area of Emeishan large igneous province. Data sources: Zhang et al. (1988), Yuan (1995), and Liu et al. (2001). B: Seismic velocity (Vp) structure of lower crust and upper mantle along profile A-B shown in A (modified after Liu et al., 2001). HVLC_high-velocity lower crust.

this body might represent the residues left after extensive melt extraction from the plume head. Strongly refractory (olivine rich) mantle is low in density, which translates to high compressional velocities. In addition, the high $V \mathrm{p}$ body is at a depth of $>100 \mathrm{~km}$ (Fig. 3B), where garnet is stable. An assemblage of olivine and garnet with subordinate pyroxenes would have a characteristically high seismic velocity (Farnetani et al., 1996).

A genetic link between the crust-mantle structure and a mantle plume is thus inferred. The thicker crust in the inner zone reflects high melt production resulting from the higher temperature in the central part of the plume and uplift of lithosphere above the plume head that triggered relatively high amounts of decompression melting (Fig. 4). High melt production may lead to cooling and fractionation of melts at the crust-mantle boundary, thereby creating cumulate rocks that form the high-velocity lower crust (Farnetani et al., 1996).

\section{FOSSIL MANTLE PLUME IN THE EMEISHAN LARGE IGNEOUS PROVINCE}

While a heated debate rages around the existence of mantle plumes, this study provides compelling evidence for a fossil mantle plume beneath the Emeishan flood-basalt province of southwest China. Sedimentologic and paleogeographic data show unequivocal evidence for a lithospheric doming event prior to the Emeishan volcanism. In turn this analysis provides a unique framework within which to interpret data from many disciplines. Systematic geochemical and geo- 


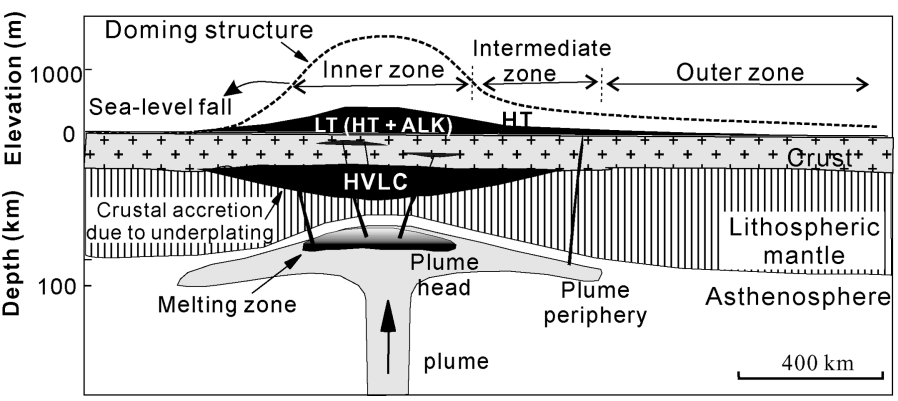

Figure 4. Surface uplift, generation of Emeishan basalts, and crustal accretion in context of upwelling of mantle plume. HVLC - highvelocity lower crust; HT-high-Ti basalt; LT-low-Ti basalt; ALKalkaline series.

physical variations and geologic observations in and around the Emeishan large igneous province are best explained in terms of plume involvement in flood volcanism. Specifically, the consequences of plume-lithosphere interaction (Fig. 4) include (1) sedimentologic evidence for kilometer-scale, prevolcanic uplift and/or doming, including thinning of marine carbonates, a marine to subaerial transition, local provenance of clastic sediments, and a marked erosional unconformity, evident as paleo-karstic surfaces on the marine carbonates; (2) a domal structure (700 km radius) active for 3 m.y.; (3) variations in the thickness of volcanic rocks across the domal structure; (4) variations in flood-basalt geochemistry from the center to the edge of the domal structure (such that picrites are restricted to the core of the dome) that are interpreted as high-temperature melts in the center and lowertemperature melts at the edge; (5) gradual decrease in crustal thickness from the center to the margin of the dome; and (6) the presence of a high-velocity region of upper mantle at a depth of $\sim 100 \mathrm{~km}$ and highvelocity lower crust $(15-25 \mathrm{~km})$ immediately beneath the domal structure consistent with significant melt production and possible underplating and/or intrusion into the lower crust.

\section{ACKNOWLEDGMENTS}

The study was supported by the National Science Foundation of China (40234046), the Chinese Academy of Sciences (KZCX2-101), and the Ministry of Science and Technology (G1999043205). We thank R. Ernst, an anonymous referee, and B.A. van der Pluijm for constructive reviews.

\section{REFERENCES CITED}

Anderson, D.L., 2001, Top-down tectonics: Science, v. 293, p. 2016-2018.

Campbell, I.H., and Griffiths, R.W., 1990, Implications of mantle plume structure for the evolution of flood basalts: Earth and Planetary Science Letters, v. 99, p. $79-93$.

Chung, S.L., and Jahn, B.M., 1995, Plume-lithosphere interaction in generation of the Emeishan flood basalts at the Permian-Triassic boundary: Geology, v. 23 , p. $889-892$.

Coffin, M.F., and Eldholm, O., 1994, Large igneous provinces: Crustal structure, dimension, and external consequences: Reviews of Geophysics, v. 32, p. 1-36.

Courtillot, V., and Renne, P.R., 2003, On the ages of flood basalt events: Comptes Rendus Geosciences, v. 335, p. 113-140.

Courtillot, V., Davaillie, A., Besse, J., and Stock, J., 2003, Three distinct types of hotspots in the Earth's mantle: Earth and Planetary Science Letters, v. 205 , p. $295-308$.

Cox, K.G., 1989, The role of mantle plumes in the development of continental drainage patterns: Nature, v. 342, p. 873-877.

Cui, Z.Z., Luo, D.Y., Chen, J.P., Zhang, Z.Y., and Huang, L.Y., 1987, Deep crust structure and tectonics in the Panxi area: Acta Geophysica Sinica, v. 30 , p. $566-579$.

Czamanske, G.K., Gurevich, A.B., Fedorenko, V., and Simonov, O., 1998, De- mise of the Siberian plume: Paleogeographic and paleotectonic reconstruction from the prevolcanic and volcanic records, north-central Siberia: International Geology Review, v. 40, p. 95-115.

DePaolo, D., and Manga, M., 2003, Deep origin of hotspots-Is only seeing believing?: Science, v. 300, p. 920-921.

Ernst, R.E., and Buchan, K.L., 2003, Recognizing mantle plumes in the geological record: Annual Review of Earth and Planetary Sciences, v. 31, p. $460-523$.

Farnetani, C.G., Richards, M.A., and Ghiorso, M.S., 1996, Petrological models of magma evolution and deep crustal structure beneath hotspots and flood basalts: Earth and Planetary Science Letters, v. 143, p. 81-94.

Feng, Z.Z., Yang, Y.Q., and Jin, Z.K., 1997, Lithofacies paleography of Permian of south China: Beijing, Petroleum University Press, 242 p.

Foulger, G.R., and Natland, J.H., 2003, Is "hotspot" volcanism a consequence of plate tectonics?: Science, v. 300, p. 921-922.

Hallam, A., and Wignall, P., 1999, Mass extinctions and sea-level change: EarthScience Reviews, v. 48, p. 217-250.

He, B., Xu, Y.-G., Chung, S.-L., Xiao, L., and Wang, Y., 2003, Sedimentary evidence for a rapid crustal doming prior to the eruption of the Emeishan flood basalts: Earth and Planetary Science Letters, v. 213, p. 389-403.

Liu, J., Liu, F., He, J., Chen, H., and You, Q., 2001, Study of seismic tomography in Panxi paleorift area of southwestern China-Structural features of crust and mantle and their evolution: Science in China, ser. D, v. 44, p. 277-288.

McKenzie, D.P., and Bickle, M.J., 1988, The volume and composition of melt generated by extension of the lithosphere: Journal of Petrology, v. 29 , p. 625-679.

McKenzie, D.P., and O'Nions, R.K., 1991, Partial melt distributions from inversion of rare earth element concentrations: Journal of Petrology, v. 32, p. $1021-1091$.

Menzies, M.A., Klemperer, S.L., Ebinger, C.J., and Baker, J., 2002, Characteristics of volcanic rifted margins, in Menzies, M.A., et al., eds., Volcanic rifted margins: Geological Society of America Special Paper 362, p. 1-14.

Montelli, R., Nolet, G., Dahlen, F.A., Masters, G., Engdahl, E.R., and Hung, S.H., 2004, Finite-frequency tomography reveals a variety of plumes in the mantle: Science, v. 303, p. 338-343.

Morgan, W.J., 1971, Convection plumes in the lower mantle: Nature, v. 230, p. $42-43$.

Rainbird, R.H., and Ernst, R.E., 2001, The sedimentary record of mantle-plume uplift, in Ernst, R.E., and Buchan, K.L., eds., Mantle plumes: Their identification through time: Geological Society of America Special Paper 352, p. 227-245.

Sheth, H.C., 1999, Flood basalts and large igneous provinces from deep mantle plumes: Fact, fiction, and fallacy: Tectonophysics, v. 311, p. 1-29.

White, R.S., and McKenzie, D., 1989, Magmatism at rift zone: The generation of volcanic continental margins and flood basalts: Journal of Geophysical Research, v. 94, p. 7685-7729.

Xiao, L., Xu, Y.-G., Chung, S.-L., He, B., and Mei, H.J., 2003, Chemostratigraphic correlation of Upper Permian lava succession from Yunnan Province, China: Extent of the Emeishan large igneous province: International Geology Review, v. 45, p. 753-766.

Xu, Y.-G., Chung, S.-L., Jahn, B.M., and Wu, G.Y., 2001, Petrologic and geochemical constraints on the petrogenesis of Permian-Triassic Emeishan flood basalts in southwestern China: Lithos, v. 58, p. 145-168.

Xu, Y.-G., Mei, H.J., Xu, J.F., Huang, X.L., Wang, Y.J., and Chung, S.-L., 2003, Origin of two differentiation trends in the Emeishan flood basalts: Chinese Science Bulletin, v. 48, p. 390-394.

Yuan, X.C., 1995, Geophysical maps of China: Beijing, Geological Publishing House, $200 \mathrm{p}$

Zhang, Y.X., Luo, Y., and Yang, X., 1988, The Panxi rift: Beijing, Geological Press, $324 \mathrm{p}$.

Zhou, M., Malpas, J., Song, X., Robinson, P.T., Sun, M., Kennedy, A.K., Lesher, C.M., and Keays, R.R., 2002, A temporal link between the Emeishan large igneous province (SW China) and the end-Guadalupian mass extinction: Earth and Planetary Science Letters, v. 196, p. 113-122.

Manuscript received 24 February 2004

Revised manuscript received 26 May 2004

Manuscript accepted 9 June 2004

Printed in USA 